\title{
Association of Insulin Growth Factor 2 Binding Protein 2 Gene rs4402960 Polymorphism with Type 2 Diabetes Mellitus in A Sample from Egyptian Patients
}

\author{
YASSER M. ISMAEL, M.D.; SAHAR M. FAYED, M.D.; DALIA M. ABD EL-HASSIB, M.D. and \\ BASMA G.A. BEHAIRY, M.Sc. \\ The Department of Clinical \& Chemical Pathology, Faculty of Medicine, Benha University, Egypt
}

\begin{abstract}
Background: Genetic variation at the insulin growth factor 2 binding protein 2 (IGF2BP2) gene has been associated with Type 2 Diabetes (T2DM) by genome-wide association studies.

Aim of Study: To assess the genetic association of insulin growth factor 2 binding protein 2 (IGF2BP2) rs4402960 polymorphism with the development of type 2 diabetes mellitus in a sample from Egyptian patients.

Patients and Methods: 50 subjects; $30 \mathrm{~T}_{2} \mathrm{DM}$ patients and 20 healthy controls. They were subjected to: History, clinical examination, measuring glycosylated hemoglobin, lipid profile and genotyping of IGF 2BP2 (rs4402960) using Taqman-based allelic discrimination technique by Real-Time PCR.

Results: There was significant statistical difference regarding allele frequency of IGF2BP2 (rs4402960) as it exhibited an increased $\mathrm{T}$ allele frequency in the diabetic group while $\mathrm{G}$ allele was decreased compared to controls. The allelic association analysis confirmed a significant association with $\mathrm{T}_{2} \mathrm{DM}[\mathrm{OR}=7.43, p=<0.001]$. The frequency of $(\mathrm{G} / \mathrm{T}+\mathrm{T} / \mathrm{T})$ genotypes vs. $\mathrm{G} / \mathrm{G}$ was significantly higher in $\mathrm{T}_{2} \mathrm{DM}$ patients than in controls $[p=0.022, \mathrm{OR}=0.26]$.

Conclusion: IGF2BP2 rs4402960 was significantly associated with increased risk of $\mathrm{T}_{2} \mathrm{DM}$ and can be used to predict the disease in Egyptian patients, and it is recommended to do this study on a large scale to confirm this association.
\end{abstract}

Key Words: Genome-wide association - IGF ${ }_{2} \mathrm{BP}_{2}-$ Type 2 diabetes mellitus - Real-Time PCR.

\section{Introduction}

DIABETES mellitus defined as a chronic, progressive metabolic condition mostly characterized by hyperglycemia. The commonest reasons which contribute to the pathophysiology of $\mathrm{T}_{2} \mathrm{DM}$ are impaired insulin secretion, insulin resistance, or a

Correspondence to: Dr. Basma G.A. Behairy, E-Mail: basmagala1235@gmail.com combination of both [1]. Type 2 diabetes mellitus $\left(\mathrm{T}_{2} \mathrm{DM}\right)$ is a polygenic disorder which caused by a complex interaction between environmental and genetic factors [2]. By the year 2030, there will be 8.6 million adults with diabetes in Egypt, making it the country with the tenth largest population of diabetics in the world [3]. Over the past several years, the Genome-Wide Association Studies (GWAS) have identified approximately 40 susceptibility loci which play roles in insulin secretion and pancreatic $\beta$-cell function [4]. Insulin-like growth factor 2 (IGF 2) is a growth-promoting polypeptide. It shares a high degree of structural homology with insulin [5].

IGF2 has a role in glucose homeostasis through increasing peripheral glucose uptake in different tissues and inhibition of hepatic gluconeogenesis and lipolysis [6]. The functions of Insulin-like growth factor 2 is binding to the 5'-UTR of the Insulin-like Growth Factor 2 (IGF) mRNA, it is stated to be involved in growth, development, cell differentiation and metabolism [7]. Insulin-like growth factor 2 mRNA binding protein 2 (IGF 2BP2) belongs to a family of IGF2 mRNA-binding proteins which implicated in mRNA localization, turnover, and IGF 2 translational regulation [8] IGF2BP2 gene located on chromosome 3q27.2 [9] IGF2BP2 has shown conflicting results regarding the nature of its association with $\mathrm{T}_{2} \mathrm{DM}$, particularly the SNP of this gene rs4402960 that was analyzed in different populations and yielded both strong $[10,11]$. As well as weak or no association [12].

Due to the disparity of results among different populations, we aimed at studying such association in Egyptian populations having $\mathrm{T}_{2} \mathrm{DM}$. This study was designed to assess the genetic association of insulin growth factor 2 binding protein 2 (IGF 2BP2) 
polymorphism (rs4402960) with type 2 diabetes mellitus (T2DM) among Egyptian populations.

\section{Patients and Methods}

This is a cross-sectional controlled study conducted at Endocrinology Outpatient Clinic in Benha University Hospitals during the period from December 2016 to June 2017. Two groups of subjects were enrolled; group 1 (diabetic group) included 30 patients with type 2 diabetes mellitus their diagnosis was based on their medical records and fulfilling the diagnostic criteria of American Diabetes Association that specifies any of the Following Fasting Plasma Glucose (FPG) $>126 \mathrm{mg} / \mathrm{dl}$ or 2h Post-Prandial Plasma Glucose (PPG) > 200mg/dl or random plasma glucose (Random Blood Sugar) (RBS) $>200 \mathrm{mg} / \mathrm{dl}$ or hemoglobin A1c (HbA1c) level $>6.5 \%$ [13]. Group 2 (control group) included 20 healthy control subjects without personal or family history of DM. Inclusion criteria for group 1: Diabetic patient's age between $35-60$ years, patient's body mass index is up to $30 \mathrm{Kg} / \mathrm{m}^{2}$. Exclusion criteria for group 1: Other types of diabetes (including $\mathrm{T}_{1} \mathrm{DM}$, or Maturity-Onset Diabetes of the Young [MODY]), renal disease, hepatic disease, endocrinal disease and metabolic disorders. The study gained approval from the Ethical Committee of the Faculty of Medicine, Benha University. Informed written consent was obtained from all subjects after fully informed about all study procedures.

\section{Methods:}

-All subjects were subjected to full history taking and physical examination including; Body Mass Index (BMI) that was calculated as weight/height ${ }^{2}$ $\left(\mathrm{kg} / \mathrm{m}^{2}\right)$.

- Peripheral blood samples $(7 \mathrm{ml})$ were collected for routine workup, including Complete Blood Count (CBC), glycosylated hemoglobin ( $\mathrm{HbA1c})$ (\%), blood glucose level (fasting and 2 hours post prandial) $(\mathrm{mg} / \mathrm{dl})$ and Lipid profile $(\mathrm{mg} / \mathrm{dl})$.

- IGF2BP2 SNP genotyping.

Genomic DNA was isolated from $200 \propto 1$ EDTA blood using blood genome DNA extraction kits (G-spinTM total DNA Extraction Kit 50 columns (cat No 17045) (lot NO 15250849) INtRON Biotechnology according to the manufacturer's protocol. IGF2BP2 rs4402960 polymorphism genotyping was performed by TaqMan-based allelic discrimination method using Step One TMReal Time PCR (Applied Biosystem, Thermal Cycling Block S/N (271003648), Foster City, California, USA). All primers and probe were designed by Applied Bio- system (Foster City, CA). The following primer pairs were used:

\section{Forward primer:}

5 tGGAGCAGTAAGGTAGGATGGACAGT AGATT-3 t.

\section{Reverse primer:}

AAGATACTGATTGTGTTTGCAAACATGCCC-3 t.

\section{VIC/FAM probe sequence: $3 t$. \\ 5t-AGTAAGGTAGGATGGACAGTAGATT-}

The PCR Master Mix Kit (2X) (Cat. No. 25341/ 25342) contained Real MOD TMReal-time PCR solution $(1 \mathrm{ml})$. The real-time cycler conditions were; initial denaturation $5 \mathrm{~min}, 95^{\circ} \mathrm{C}$, cycling $(40$ cycles: Denaturation, $5 \mathrm{sec}, 95^{\circ} \mathrm{C}$ and Denaturation/ Annealing, $\left.34 \mathrm{sec}, 60^{\circ} \mathrm{C}\right)$. Detection of SNP (G/T) Genotyping: As each SNP genotyping allele labeled with specific taqMan probe one labeled by (VIC) dye which represents allele 1 sequence for $(\mathrm{T})$ typing, and another by (fam) dye which represents allele 2 sequence for $(\mathrm{G})$ typing. The analysis is taken from the endpoint read of fluorescence.

\section{Statistical analysis:}

Data were tabulated, coded then analyzed using the STATA version 11 (STATA Corporation, College Station, Texas). Quantitative data were presented as mean $\pm \mathrm{SD}$. Student $t$-test was used to compare two groups. Pearson's correlation coefficient was used to test the correlation between variables and Chi-square test was used to compare the frequency of qualitative variables among the different groups. The Odd's Ratio (OR) and 95\% Confidence Interval $(95 \%$ CI) were for risk estimation. The level of significance was set at $p<0.05$.

\section{Results}

The clinical data of studied groups were shown in (Table 1). There was no significant difference between studied groups except for significant increased positive family history, BMI, SBP and DBP as they were higher in the diabetic group $(p<0.001)$. Regarding laboratory data, there was a statistical significant difference between studied groups regarding their FBS, PPS, $\mathrm{HBA}{ }_{1} \mathrm{C} \%$ and lipid profile (TG, TC, HDL-C, LDL-C) as it was higher in the diabetic group $(p<0.001)$ (Table 2$)$.

Regarding genotype, the $\mathrm{T}$ allele frequency was significantly higher in T2DM patients than in controls $(p<0.001)$, with $\mathrm{G} / \mathrm{G}$ genotype, was the most frequent in controls $(60 \%)$. The frequency of 
$(\mathrm{G} / \mathrm{T}+\mathrm{T} / \mathrm{T})$ genotypes vs. G/G genotype was significantly higher in T2DM patients than in control $(83.33 \%$ vs. $16.76 \%$ in patients and $40 \%$ vs. $60 \%$ in controls, respectively). (GG, TT, GG $+\mathrm{GT}$, and TT) there was a statistically significant difference between studied groups as it was higher in the diabetic group while GG was lower, but there was no a statistical significant difference between studied groups regarding genotype (GT). $\mathrm{G}$ allele is protective but $\mathrm{T}$ allele is an independent risk factor for T2DM (Table 3).

Association between the different genotype groups (GG, TT, GT) of IGF 2BP2 polymorphisms and sex, age, BMI, SBP, DBP, $\mathrm{HbA}_{1} \mathrm{c} \%$, serum lipid levels, FBG, PPBG, CBC, liver function, kidney function, age of onset, duration and complication of diabetes showed that there were no significant statistical differences between them.

Multiple logistic regressions were developed to identify significant predictors for T $2 \mathrm{DM}$ conditioned on genotype and other risk factors demonstrated that T2DM was associated TT genotype (OR; 95\% CI: 38.0; 2.50 to 576.49 and $p=0.009$ ). High BMI was associated with increased risk of T2DM (3.46; 1.53 to 7.83 and $p=0.003$ ) (Table 4).

Table (1): Comparisons between studied groups regarding their socio-demographic characteristics and their clinical data.

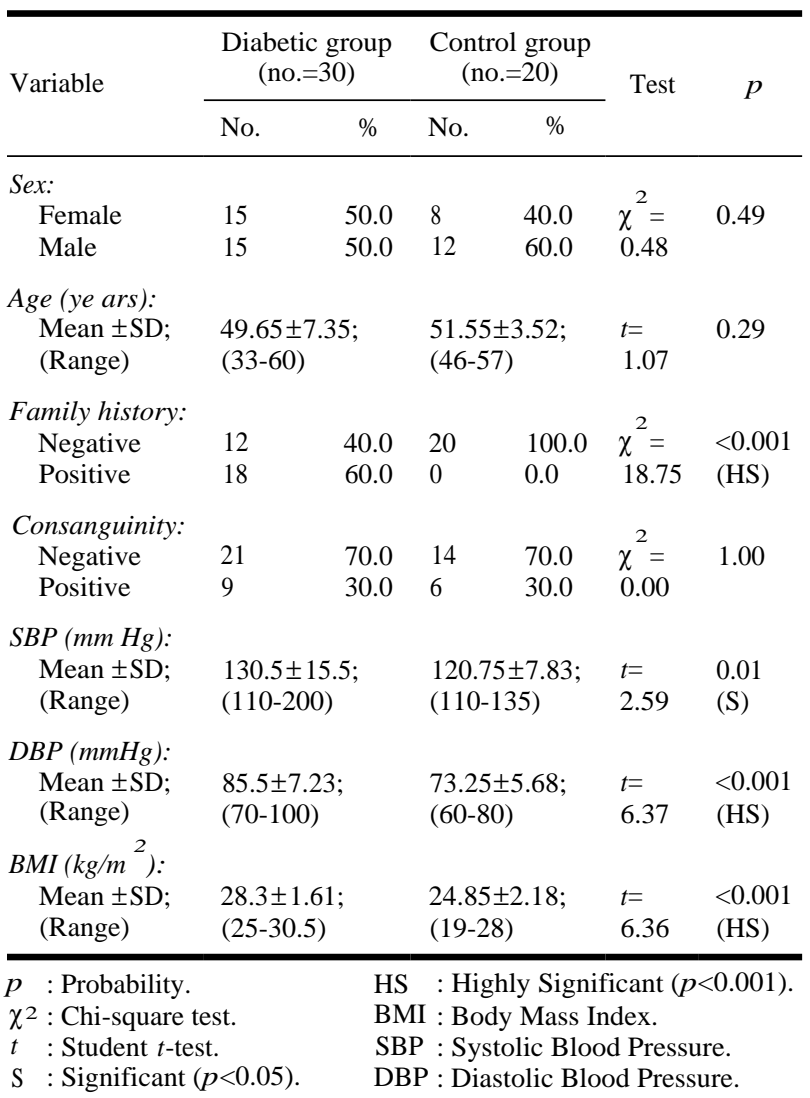

Table (2): Comparisons between studied groups regarding their laboratory data.

\begin{tabular}{|c|c|c|c|c|}
\hline Variable & \multicolumn{2}{|c|}{$\begin{array}{l}\text { Diabetic group Control group } \\
\qquad(\text { no. }=30) \\
(\text { no. }=20)\end{array}$} & Test & $p$ \\
\hline $\begin{array}{l}F B S(m g / d l): \\
\quad \text { Mean } \pm \mathrm{SD} \\
\quad \text { (Range) }\end{array}$ & $\begin{array}{l}128.47 \pm 39.78 \\
(85-287)\end{array}$ & $\begin{array}{l}86.05 \pm 8.92 \\
(70-100)\end{array}$ & $\begin{array}{l}\text { Mann- } \\
\text { Whitney } \\
\text { test=5.23 }\end{array}$ & $\begin{array}{l}<0.001 \\
(\mathrm{HS})\end{array}$ \\
\hline $\begin{array}{l}P B S(m g / d l): \\
\quad \text { Mean } \pm \mathrm{SD} \\
\quad \text { (Range) }\end{array}$ & $\begin{array}{l}260.2 \pm 72.72 \\
(120-393)\end{array}$ & $\begin{array}{l}153 \pm 28.22 \\
(100-199)\end{array}$ & 6.27 & $\begin{array}{l}<0.001 \\
(\mathrm{HS})\end{array}$ \\
\hline $\begin{array}{l}H B A 1 C \%: \\
\quad \text { Mean } \pm \mathrm{SD} \\
\quad \text { (Range) }\end{array}$ & $\begin{array}{l}7.36 \pm 0.68 \\
(6-8.8)\end{array}$ & $\begin{array}{l}5.03 \pm 0.46 \\
(4.5-6.5)\end{array}$ & 13.35 & $\begin{array}{l}<0.001 \\
\text { (HS) }\end{array}$ \\
\hline $\begin{array}{l}T G(m g / d l): \\
\quad \text { Mean } \pm \mathrm{SD} \\
\quad \text { (Range) }\end{array}$ & $\begin{array}{l}166.53 \pm 68.17 \\
(60-360)\end{array}$ & $\begin{array}{l}77.85 \pm 14.32 \\
(55-107)\end{array}$ & 5.71 & $\begin{array}{l}<0.001 \\
\text { (HS) }\end{array}$ \\
\hline $\begin{array}{l}T C(m g / d l): \\
\quad \text { Mean } \pm \mathrm{SD} \\
\quad \text { (Range) }\end{array}$ & $\begin{array}{l}212 \pm 34.05 \\
(145-300)\end{array}$ & $\begin{array}{l}167.21 \pm 22.08 ; \\
(116-214)\end{array}$ & 5.08 & $\begin{array}{l}<0.001 \\
(\mathrm{HS})\end{array}$ \\
\hline $\begin{array}{l}H D L-C(m g / d l) \\
\quad \text { Mean } \pm \mathrm{SD} \\
\quad \text { (Range) }\end{array}$ & $\begin{array}{l}45.63 \pm 9.31 \\
(20.5-62)\end{array}$ & $\begin{array}{l}47.3 \pm 9.6 \\
(31-67)\end{array}$ & 0.61 & 0.54 \\
\hline $\begin{array}{l}L D L-C(m g / d l) \\
\quad \text { Mean } \pm \mathrm{SD} \\
\quad \text { (Range) }\end{array}$ & $\begin{array}{l}127.79 \pm 26.61 ; \\
(75-179.9)\end{array}$ & $\begin{array}{l}102.93 \pm 19.33 \\
(71.4-143)\end{array}$ & 3.59 & $\begin{array}{l}<0.001 \\
\text { (HS) }\end{array}$ \\
\hline $\begin{array}{ll}p & : \text { Prot } \\
\chi^{2} & : \text { Chi- } \\
t & : \text { Stuc } \\
\text { S } & : \text { Sigr } \\
\text { HS } & : \text { Hig } \\
\text { FBS } & : \text { Fast } \\
\text { PPS } & : \text { Post } \\
\text { HBA1C\% } & : \text { Gly } \\
\text { TG } & : \text { Trig } \\
\text { TC } & : \text { Tota } \\
\text { HDL-C } & : \text { Hig } \\
\text { LDL-C } & : \text { Low }\end{array}$ & $\begin{array}{l}\text { ability. } \\
\text { square test. } \\
\text { ent } t \text {-test. } \\
\text { ificant }(p<0.05) \text {. } \\
\text { ly Significant ( } p \\
\text { ng Blood Sugar. } \\
\text { Prandial Sugar. } \\
\text { osylated Hemoglc } \\
\text { ycerides. } \\
\text { I Cholesterol. } \\
\text {-Density Lipopro } \\
\text {-Density Lipoprot }\end{array}$ & $\begin{array}{l}<0.001) \text {. } \\
\text { obin. } \\
\text { teins. } \\
\text { teins. }\end{array}$ & & \\
\hline
\end{tabular}

Table (3): Comparison between studied groups regarding their genotype and frequency of each allele of IGF 2BP2 gene polymorphism.

\begin{tabular}{|c|c|c|c|c|c|c|c|}
\hline \multirow{2}{*}{$\begin{array}{l}\text { IGF2BP2 } \\
\text { polymor } \\
\text { phisms }\end{array}$} & \multicolumn{2}{|c|}{$\begin{array}{c}\text { Cases } \\
(\text { no. }=30)\end{array}$} & \multicolumn{2}{|c|}{$\begin{array}{l}\text { Controls } \\
(\text { no. }=20)\end{array}$} & \multirow{2}{*}{$\begin{array}{l}\text { Chi- } \\
\text { square } \\
\text { test }\end{array}$} & \multirow{2}{*}{$p$} & \multirow{2}{*}{$\begin{array}{c}\text { OR } \\
(95 \% \mathrm{CI})\end{array}$} \\
\hline & No. & $\%$ & No. & $\%$ & & & \\
\hline - GG & 5 & 16.67 & 12 & 60.0 & 14.97 & $\begin{array}{c}\cdot 0.001 \\
(\mathrm{~S})\end{array}$ & - 1.00 \\
\hline • GT & 9 & 30.0 & 7 & 35.0 & 2.43 & • 0.12 & $\begin{array}{l}\cdot 3.08(0.6 \text { to } \\
16.65)\end{array}$ \\
\hline • TT & 16 & 53.33 & 1 & 5.00 & 15.07 & $\begin{aligned} \cdot & <0.001 \\
& (\mathrm{HS})\end{aligned}$ & $\begin{array}{r}-38.4(3.52 \\
\quad \text { to } 1739.68)\end{array}$ \\
\hline $\begin{array}{l}\text { - } \mathrm{GG}+ \\
\mathrm{GT}\end{array}$ & 14 & 46.67 & 19 & 95.0 & 12.49 & $\begin{aligned} \cdot<0.001 \\
\\
(\mathrm{HS})\end{aligned}$ & $\begin{array}{c}-21.71(2.60 \\
\text { to } 957.14)\end{array}$ \\
\hline$\bullet \mathrm{TT}$ & 16 & 53.33 & 1 & 5.00 & & & \\
\hline $\begin{array}{l}\cdot \mathrm{TT}+ \\
\mathrm{GT}\end{array}$ & 25 & 83.33 & 8 & 40.0 & 10.04 & $\begin{array}{c}\cdot 0.002 \\
(\mathrm{~S})\end{array}$ & $\begin{array}{l}\cdot 7.5(1.72 \text { to } \\
34.86)\end{array}$ \\
\hline • GG & 5 & 16.67 & 12 & 60.0 & & & \\
\hline$\bullet \mathrm{G}$ & $19 / 60$ & 31.67 & $31 / 40$ & 77.50 & 20.17 & $\begin{aligned} \cdot & <0.001 \\
& (\mathrm{HS})\end{aligned}$ & $\begin{array}{c}-7.43(2.73 \\
\text { to } 21.03)\end{array}$ \\
\hline$\cdot \mathrm{T}$ & $41 / 60$ & 68.33 & $9 / 40$ & 22.5 & & & \\
\hline $\begin{array}{l}p: \text { Prob } \\
\text { OR : Odd }\end{array}$ & $\begin{array}{l}\text { ability. } \\
\text { Ratio. }\end{array}$ & & S & $\% \mathrm{CI}$ & $\begin{array}{l}\text { 95\% C } \\
\text { Signifi } \\
\text { Highly }\end{array}$ & $\begin{array}{l}\text { onfidence } \\
\text { cant }(p<0 \\
\text { Significa }\end{array}$ & $\begin{array}{l}\text { Interval. } \\
.05) \text {. } \\
\text { ant }(p<0.001) \text {. }\end{array}$ \\
\hline
\end{tabular}


Table (4): Multiple logistic regressions for T2DM conditioned on genotype and other risk factors to identify significant predictors.

\begin{tabular}{|c|c|c|c|c|c|c|}
\hline \multirow{2}{*}{ Variable } & \multicolumn{2}{|c|}{$\begin{array}{l}\text { Recessive model (TT vs. } \\
\text { GT + GG) }(\text { no. }=50)\end{array}$} & \multicolumn{2}{|c|}{$\begin{array}{c}\text { Dominant model (TT vs. } \\
\text { GG) (no. }=34)\end{array}$} & \multicolumn{2}{|c|}{$\begin{array}{l}\text { Additive model (T vs. G) } \\
\text { (no. }=100)\end{array}$} \\
\hline & OR $(95 \% \mathrm{CI})$ & $p$ & OR $(95 \% \mathrm{CI})$ & $p$ & OR $(95 \% \mathrm{CI})$ & $p$ \\
\hline IGF2BP2 polymorphisms & $38.0(250$ to 576.49$)$ & 0.009 & $8.54(1.49$ to 49.02$)$ & 0.016 & $11.01(2.69$ to 45.11$)$ & 0.001 \\
\hline BMI $\left(\mathrm{kg} / \mathrm{m}^{2}\right)$ & $3.46(1.53$ to 7.83$)$ & 0.003 & $3.73(1.19$ to 11.68$)$ & 0.024 & $3.04(1.9$ to 4.86$)$ & $<0.001$ \\
\hline
\end{tabular}

\section{Discussion}

Insulin-like growth factor 2 mRNA-binding protein $2\left(\mathrm{IGF}_{2} \mathrm{BP}_{2}\right)$ has a role in the stimulation of insulin action. Polymorphisms in the $\mathrm{IGF}_{2} \mathrm{BP}_{2}$ gene have been analyzed in various studies to assess association of these variants with the type 2 diabetes (T2DM), but results are conflicting [14] . Our study show that there was a statistically significant difference between studied groups regarding genotype (GG, TT, GG $+\mathrm{GT}$, and TT) as it was higher in the diabetic group while GG was lower, also allele $\mathrm{T}$ was higher in the diabetic group. These results were in accordance with a study done by El-Lebedy et al., who stated that the variant $\mathrm{T}$ allele was associated with $\mathrm{T} 2 \mathrm{DM}$ as it was higher in T2DM patients than in controls $(p<0.001)$, with G/G genotype, was the most frequent in control subjects $(62.5 \%)$. The frequency of $(\mathrm{G} / \mathrm{T}+\mathrm{T} / \mathrm{T})$ genotypes vs. G/G genotype was significantly higher in T2DM patients $(62.5 \%)$ vs. $34.5 \%$ than in controls $(37.5 \%)$ vs. $62.5 \%,(p=$ 0.00001) [15]

Huang et al., found that the pooled ORs of the allele (T vs. G) of rs4402960 polymorphic loci in $\mathrm{IGF}_{2} \mathrm{BP}_{2}$ was a significant association with $\mathrm{T} 2 \mathrm{DM}$ $(\mathrm{OR}=1.16395 \% \mathrm{CI}=[1.138,1.189] p<0.00001)$ [16].

These results were also consistent with previous finding of Rao et al., who reported that the carriers of TT genotype at rs4402960 had a higher T2DM risk than the $\mathrm{G}$ carriers $(\mathrm{TG}+\mathrm{GG})(95 \%$ confidence interval $(95 \% \mathrm{CI})=1.065-3.612, p=0.031][17]$.

The study of Benrahma et al., demonstrated that the genotypic distribution of the rs 4402960 polymorphism in $\mathrm{IGF}_{2} \mathrm{BP}_{2}$ showed that the homozygous GG genotype was $32.58 \%$, the heterozygous GT genotype $45.25 \%$, and the recessive homozygous TT $22.17 \%$, in the patient group, while in the control group, genotype frequencies were $36.40 \% \mathrm{GG}, 51.88 \% \mathrm{GT}$, and $11.72 \% \mathrm{TT}$. The statistical analysis showed that both the additive (OR 2.33, 95\% CI 1.31-4.14; $p=0.004$ ) and recessive (OR 2.23, 95\% CI 1.33-3.73; $p=0.002$ (models of rs4402960 polymorphism was signifi- cantly associated with diabetes. The frequency of the $T$ allele was $37.66 \%$ and the $G$ allele was $62.34 \%$ in the controls. A comparison of these frequencies to those observed in the patient group ( $\mathrm{T} 47.8 \%$ and $\mathrm{G} 55.20 \%$ ) revealed that the $\mathrm{T}$ allele was associated with susceptibility to diabetes (OR 1.34, 95\% CI 1.032-1.74; $p=0.027$ ) [18].

On the other hand, a study performed by. Kommoju et al., reported that the allele and genotype frequencies were similar between cases and controls, for SNP of $\mathrm{IGF}_{2} \mathrm{BP}_{2}$ rs4402960. Multiple logistic regressions did not reveal significant allelic or genotypic association of this SNP with T 2DM [19].

Wu et al., found that $\mathrm{IGF}_{2} \mathrm{BP}_{2}(\mathrm{rs} 4402960)$ rs4402960 was not significantly associated with T2DM and it had a protective effect against type 2 DM in obese subjects [20]

In the present study, there were no significant statistical differences between the different genotype groups regarding sex, age, SBP, DBP, $\mathrm{HBA}_{1} \mathrm{C} \%$, serum lipid levels, FBG, PPBG, CBC, liver function, kidney function, an age of onset, duration and complication of diabetes.

These results were in agreement with Rodriguez et al., who showed that no significant association was found between hypertension status or serum lipid levels among genotype subgroups. $(p>0.05$ for all) [21]

However, there was a conflicted finding as Rao et al., demonstrated that there was significant associations were identified for rs 4402960 in all gene of cases, regarding there diagnostic criterion, sample size, sex, average age and BMI [17]. Also, El-Lebeedy et al., showed a significant association with T2DM regarding the covariates gender, BMI, TGs, and HDL-c [15].

Multiple Logistic Regressions (MLR) were developed to identify significant predictors for T2DM conditioned on genotype and other risk factors demonstrated that T2DM was associated TT genotype (OR; 95\% CI: $38.0 ; 2.50$ to 576.49 and $p=0.009$ ). High BMI was associated with 
increased risk of $\mathrm{T}_{2} \mathrm{DM}(3.46 ; 1.53$ to 7.83 and $p=0.003$ ).

Wu et al., agreed with our results by multiple logistic regressions models which were developed to demonstrate that obesity (BMI > $28.0 \mathrm{~kg} / \mathrm{m}^{2}$ ) remained an independent risk factor for $\mathrm{T}_{2} \mathrm{DM}$ after potential confounder adjustment $(p<0.05)$. While rs4402960 alone was not significantly associated with $\mathrm{T}_{2} \mathrm{DM}$. Both BMI and SNP rs4402960 which were detected in MLR models only confirmed a significant association between this SNP and $\mathrm{T}_{2} \mathrm{DM}$ in the high-BMI group ( $p=0.008$ for allele analysis and $p<0.001$ for genotype analysis) [20].

Ruchat et al., stated that IGF 2BP2 had a possible role in insulin resistance as he was found that the associations between the variant of IGF $2 \mathrm{BP} 2$ and abdominal/visceral total fat were evidenced in Canadian Caucasians. According to this finding IGF2BP2 (rs4402960) may disturb $\mathrm{T}_{2} \mathrm{DM}$ susceptibility through its contribution to insulin resistance, which is experienced mainly by the obese individual [22].

Kargun et al., found no statistically significant difference between morbidly obese persons and non-obese individuals in terms of IGF $2 \mathrm{BP} 2$ gene rs4402960 gene polymorphism and it's allele frequencies this may be due to a small size of samples which included in the study [23].

\section{Conclusion:}

The IGF2BP2 gene rs4402960 polymorphism was found to be significantly associated with increased risk of type 2 diabetes mellitus and can be used to predict the disease in Egyptian patients, and it is recommended to do this study on a large scale to confirm this association.

\section{Sources of support: No funding-no grants.}

\section{Conflict of interest: No conflict of interest.}

Auther contributions: Yasser M. Ismael: Contributed in the conception of the work, approval of the final version of the manuscript, and agreed for all aspects of the work. Sahar M. Fayed: Contributed in the conception of the work, drafting and revising the draft, approval of the final version of the manuscript, and agreed for all aspects of the work. Dalia M. Abd El-Hassib: Contributed in the conception of the work, drafting and revising the draft, approval of the final version of the manuscript, and agreed for all aspects of the work. Basma G.A. Behairy: Contributed in the conception of the work, analysis, interpretation of data for the work, approval of the final version of the manuscript, and agreed for all aspects of the work.

\section{References}

1- CHAUDHURY A., DUVOOR C., DENDI V.S., KRALETI S., CHADA A., RAVILLA R., et al.: Clinical Review of Antidiabetic Drugs: Implications for Type 2 Diabetes Mellitus Management. Front. Endocrinol., 8: 6. doi: 10.3389/fendo.2017.00006, 2017.

2- LASRAM K., BENHAЫM N., BENRAHMA H., MEDIIIENE B.S., ARFA I., HSOUNA S., KEFI R., et al.: Contribution ofCDKAL1rs7756992 and IGF 2BP2 rs4402960 polymorphisms in type 2 diabetes, diabetic complications, obesity risk and hypertension in the Tunisian population. Journal of Diabetes, 7: 102-13, doi: 10.1111/1753-0407.12147, 2015.

3- ARAFA N.A. and AMIN G.E.: The epidemiology of diabetes mellitus in Egypt: Results of a National Survey. The Egyptian Journal of Community Medicine, 28 (3): 29-35, 2010.

4- IMAMURA M., SHIGEMIZU D., TSUNODA T., IWATA M., MAEGAWA H., WATADA H., et al.: Assessing the Clinical Utility of a Genetic Risk Score Constructed Using49 Susceptibility Alleles for Type 2 Diabetes in a Japanese Population. J. Clin. Endocrinol. Metab., 98: 1667-73, 2013.

5- CASELLAS A., MALLOL C., SALAVERT A., JIMENEZ V., GARCIA M., AGUDO J., et al.: Insulin-like Growth Factor 2 Overexpression Induces b-Cell Dysfunction and Increases Beta-cell Susceptibility to Damage. The Journal of Biological Chemistry, 290 (27): 16772-85, doi: 10.1074/ jbc.M115.642041, 2015.

6- SALTIEL A.R.: Insulin Signaling in the Control of Glucose and Lipid Homeostasis Volume 233 of the series Handbook of Experimental Pharmacology, 233: 51-71, 2015.

7- KARGUN K., SENOL S., K1RKıL C., CAMBAY Z., KARA M., AYGEN E., et al.: IGF2BP2 gene polymor phism in patients with morbid obesity. Biomedical Research, 28 (2): 508-11, 2017.

8- BELL J.L., WÄCHTER K., MÜHLECK B., et al.: Insulinlike growth factor $2 \mathrm{mRNA}$-binding proteins (IGF 2BPs): post-transcriptional drivers of cancer progression? Cell Mol. Life Sci., 70 (15): 2657-75, 2013.

9- GU T., HOROVÁ E. and MÖLLSTEN A.: IGF2BP2 and IGF2 genetic effects in diabetes and diabetic nephropathy. J. Diabetes Complications, 26 (5): 393-8, 2012.

10- CAUCHI S., et al.: European genetic variants associated with type 2 diabetes in North African Arabs. Diabetes Metab, 3 8: 316-23, 2012.

11- GAMBOA MELÉNDEZ M.A., et al.: Contribution of common genetic variation to the risk of type 2 diabetes in the Mexican Mestizo,population. Diabetes, 61: 3314$21,2012$.

12- CUI B., ZHU X., XU M., GUO T., ZHU D., CHEN G., et al.: A genome-wide association study confirms previously reported loci for type 2 diabetes in Han Chinese. PLoS ONE, 6: e22353. [PubMed], 2011.

13- American Diabetes Association: Standards of Medical Care in Diabetes Care, 39 (1): 1-2, 2016. 
14- ZHAO Y., MA Y.S., FANG Y., LIU L., WU S.D., FU D., et al.: $\mathrm{IGF}_{2} \mathrm{BP}_{2}$ genetic variation and type 2 diabetes: $\mathrm{A}$ global meta-analysis. DNA Cell Biol., 31 (5): 713-20. doi: 10.1089/dna.2011.1400, 2012.

15- EL-LEBEDY D., ASHMAWY I. and ALSHAYMAA A.: Common Variants in IGF ${ }_{2} \mathrm{BP}_{2}$ Gene rs4402960 and rs1470579 Polymorphisms Associate with Type 2 Diabetes Mellitus in Egyptians: A Replication Study. International Journal of Diabetes Research, 4 (3): 43-8. doi: 10.5923/ j.diabetes.2015;0403.01, 2015.

16- HUANG Z., DONG M., LI J., QIU W. and LI S.: MetaAnalysis of the association of IGF2BP2gene rs4402960 polymorphisms with T2DM in Asia. BIO Web of Confeences, 8: 02003, Doi 10.1051/bioconf/20170802003, 2017.

17- RAO P., WANG H., FANG H., GAO Q., ZHANG J., ZHOU Y., et al.: Association between IGF ${ }_{2} \mathrm{BP}_{2}$ Polymorphisms and Type 2 Diabetes Mellitus: A Case-Control Study and Meta-Analysis Res. Public Health, 13 (6): 574, doi:10.3390/ijerph13060574, 2016.

18- BENRAHMA H., CHAROUTE H., LASRAM K., BOULOUIZ R., FAKIRI M., ROUBA H., et al.: Association Analysis ofIGF2BP2, KCNJ11, and CDKAL1 Polymorphisms with Type 2 Diabetes Mellitus in a Moroccan Population: A Case-Control Study and Meta-analysis, Biochem Genet, 52: 430-42, Doi 10.1007/s10528-0149658-5, 2014.
19- KOMMOJU U.J., MARUDA J., KADARKARAI S., IRGAM K., KOTLA J.P., DUESING K., et al.: No detectable association of $\mathrm{IGF}_{2} \mathrm{BP}_{2}$ and SLC30A8 genes with type 2 diabetes in the population of Hyderabad, India. Meta Gene, 1: 15-23, doi: 10.1016/j.mgene.2013.09.003, 2013.

20- WU H., LIU N.J., YANG Z., MING TAO X., PING DU Y., WANG X.C., LU B., ZHAO-YUN ZHANG Z.H., et al.: $\mathrm{IGF}_{2} \mathrm{BP}_{2}$ and obesity interaction analysis for type 2 diabetes mellitus in Chinese Han population. European Journal of Medical Research, 19-40, 2014.

21- RODRIGUEZ S., EIRIKSDOTTIR G., GAUNT T.R., HARRIS T.B., LAUNER L.J., GUDNASON V., et al.: IGF2BP 1, IGF $\mathrm{IPP}_{2}$ and IGF2BP3 genotype, haplotype and genetic model studies in metabolic syndrome traits and diabetes, Growth Horm IGF Res., 20 (4): 310-8, doi: 10.1016/j . ghir.2010.04.002, 2010.

22- RUCHAT S.M., ELKS C.E., LOOS R.J., VOHL M.C., WEISNAGEL S.J., RANKINEN T., et al.: Evidence of interaction between type 2 diabetes susceptibility genes and dietary fat intake for adiposity and glucose homeostasis-related phenotypes. J. Nutrigenet. Nutrigenomics., 2 (4-5): 225-34. doi: 10.1186/2047-783X-19-40, 2009.

23- KARGUN K., SENOL S., K1RK1L C., CAMBAY Z., KARA M., AYGEN E., et al.: $\mathrm{IGF}_{2} \mathrm{BP}_{2}$ gene polymorphism in patients with morbid obesity. Biomedical Research, 28 (2): 508-11, 2017.

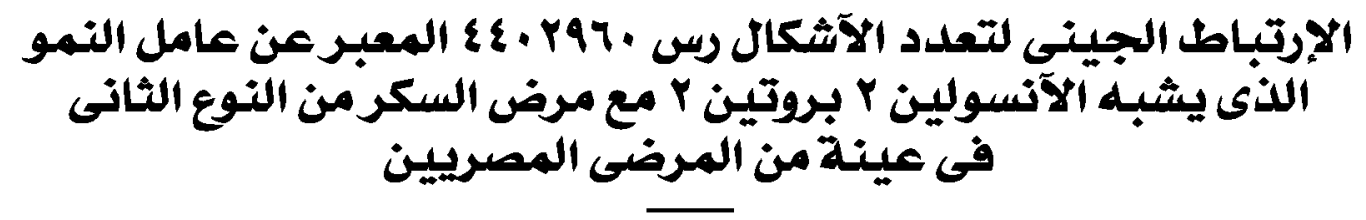

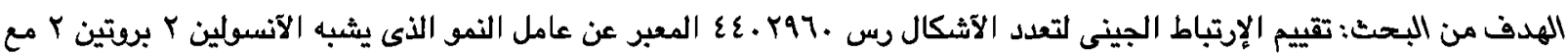

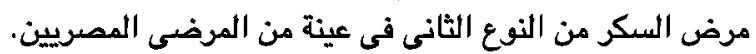

المرضى وطرق البحث: تمت هذه الدراسة على •0 شخصا من الجنسين وتم تصنيفه إلى مجموعة الدراسة: عددهم •ب مريضا مصابا

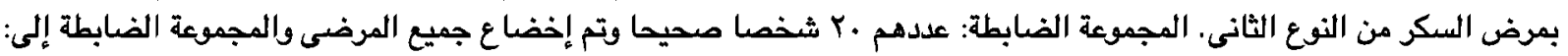
• آخذ التاريخ المرضى والفصص السريرى الدقيق وقياس نسبة الهيموجلوبين السكرى، قياس مستوى الدهون، وعمل تفاعل البلمرة المتسلسل

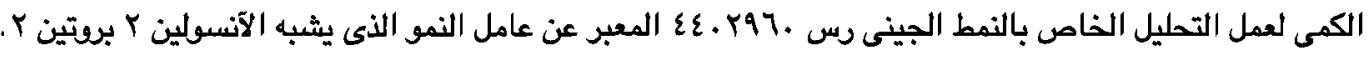

النتائج: توصل البحث إلى وجود إرتباط ذو دلالة إحصائية بين المتغير الجينى المعبر عن بروتين ب الممثل لعامل النمو الذى يشبه الآنسبلين

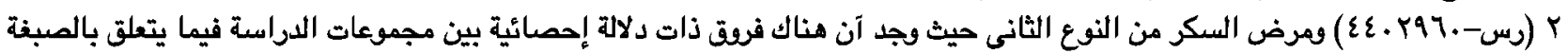

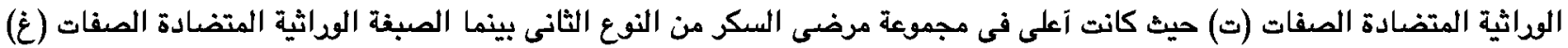

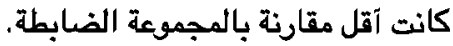

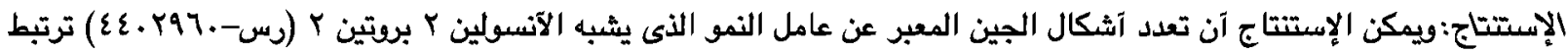

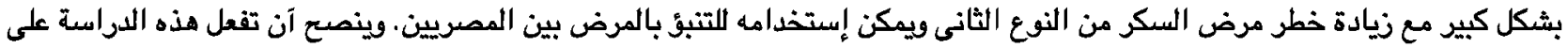
نطاق واسع لتآكيد هذا الإرتباط. 